Article

\title{
Systemic Sustainable Development in the Transport Service Sector
}

\author{
Izabela Sztangret $(\mathbb{D}$ \\ Entrepreneurship Department, University of Economics in Katowice, 40-287 Katowice, Poland; \\ izabela.sztangret@ue.katowice.pl
}

Received: 26 September 2020; Accepted: 10 November 2020; Published: 16 November 2020

\begin{abstract}
The concept of sustainability and sustainable development, especially systemic sustainable development, still raises controversy in literature. The article makes an attempt to re-examine these concepts from a systems perspective, seeking foundations and applications in the selected sector. It is becoming increasingly clear that sustainability and sustainable development are aimed at integrated economic, social, cultural, political, and ecological factors. This causes a need for a constructive approach to the issue, taking into account all the actors, areas and dimensions involved in the pursuit of systemic sustainable development. As a result, both local and global dimensions and the way they interact must be explored in a multifaceted manner in order to offer a perspective more effective and useful than other analytical approaches, as the systems view is a way of thinking in terms of connectedness, relationships, and context. The article aims to review selected publications and studies so as to form the general idea of systemic sustainable development and define the systemic development of sustainable transport, including in particular the perspective of the actors of the sector, transport providers (passenger, urban), and transport development program, implemented both by local governments and on the European scale. An attempt was made to identify elements of the systemic sustainable development model, setting it in the reality of the following subcategories: "Society", "Economy", and "Environment" in sectoral terms. It is supposed that systemic sustainable development is a conglomerate of public administration entities, companies operating in the sector, individual and corporate customers, acting in certain conditions for economic, social, and environmental well-being, and a number of their initiatives of major or minor significance, grouped in six sub-areas, undertaken to achieve systemic value in the examined sector, with a positive or negative business/economic, social, and environmental impact.
\end{abstract}

Keywords: sustainable development; systemic development; systemic sustainable transport development

\section{Systemic Sustainable Development-Introduction}

Sustainable development [1,2] (pp. 641-642) also referred to as balanced development or eco-development, is a concept and way of thinking in economics that presumes the level and quality of life to be the level as guaranteed by civilization development in appreciated time. The idea of sustainable development is summarized and showed in the first sentence of WCED (The World Commission on Environment and Development, also referred to as "Brundtland Commission") report of 1987-“'Our Common Future": "On current civilization level sustainable development is possible. Sustainable development is development that meets the needs of the present without compromising the ability of future generations to meet their own needs." This definition is connected with two principal concepts: the notion of "needs", particularly elementary needs of the poorest in the world that should be prioritized, and the notion of limitations, i.e., imposed capabilities of the environment to meet present and future needs through the level of technology and social organization. The essence of the report suggests that achieved civilizational level is possible to be retained on condition of suitable management in the domain of environment, economics, and social welfare. According to the point of view of the Club of 
Rome, included in the report entitled "Limits of Growth", the concept of sustainable development of all spheres of human life and activity should be taken care of for the purpose of ensuring further nature of life on Earth and possibilities to meet elementary needs of all the people and future generations. It arises from the definition included in standards and also documents of the United Nations that sustainable development of the Earth is the special development that meets basic needs of all people. It supports, protects and restores health and integrity of the Earth's eco-system without a threat to the capacity for satisfying the needs of future generations and without exceeding long-term limits of the capacity of the Earth's ecosystem [3,4]. Therefore, sustainable development depicts economic growth that leads to social cohesion and increased value of natural environment $[5,6]$. In Poland, the principle of sustainable development is included in clause 5 of the Polish Constitution, whereas the definition of sustainable development is encompassed in the Act entitled "Environmental Protection Law" in the following wording: "(it is) such social and economic development in which the process of integration of political, economic and social activities is observed, with maintenance of natural balance and durability of elementary natural processes, for the purpose of ensuring the possibility to satisfy elementary needs of individual communities or citizens of both present and future generations" (Act of 27 April 2001 Law on environmental protection).

The concept of sustainable development is becoming especially important in the period of knowledge society and knowledge economy where knowledge is the reason and a driving force behind the comprehensive development of individuals and economy. In this context, the concept of sustainable development in the business environment is often perceived as the synonym of behaviors associated with success and innovation, often of pro-ecological character in relationships with various groups of stakeholders, in the process of creation of systemic values, especially in a new technology environment.

Systemic development nvolves a process of adopting a holistic perspective view while addressing complex issues and progressing towards a mutual goal with high participation rates [7]. The process encompasses the understanding of current activities and future needs from a holistic perspective. To reach success, it is essential that the process should shift from integrated to sustainable assessment. The perspective should account for a variety of facets of the current and future development embracing economic, social, environmental, political, and ecological aspects. The idea behind a systemic development approach can be applied to many disciplines, just as sustainable development [8]. To successfully achieve development through a systems approach, holistic operating is necessary. A holistic approach to a system aims at each variable, space between the variables, and what defines the variable- "It's the sum of the interactions of its parts and elements" [8] (pp. 106-116). In this process, individuals must learn from each other to understand the whole system in a multidimensional way to find a solution. To think about development in terms of an entire system, one needs to be able to see the whole instead of parts and understand the relationship between the parts, the way the parts move, what drives the behavior of the parts, what influences the flow or direction, and to understand why there are no more or no fewer parts. The parts that make up the whole can be a complex system [9] (p. 99), [10].

Systemic sustainability is a process of development-individual, organizational, or societalinvolving an adaptive strategy of emergence that ensures the evolutionary maintenance of an increasingly robust and supportive environment. Systemic sustainability goes beyond the triple bottom line and embraces "the possibility that human and other forms of life will flourish on the Earth forever", as expressed by John Ehrenfeld [11]. Adam Werbach [12] defines a sustainable business as one capable of "thriving in perpetuity". Systemic sustainability is about developing this capacity so that all human systems can co-exist in partnership with the living systems of our planet.

The concept of sustainable development [13] embraces everyone and everything-it concerns a variety of aspects of human activity and man's relations with the environment, and its implementation requires cooperation between people and institutions representing different professions, starting points, and visions of the future-hence, it requires a systemic approach. Accordingly, a relatively clear concept when referred to environmental issues becomes complex, less clear if it includes the whole complex of interconnected environmental, economic, societal, and political issues. Systemic sustainable development: 
- is a type of socio-economic development, pursued by and for man, aiming at environmental and socioeconomic egalitarianism,

- is a process that integrates all human activities, commonly seen in three dimensions: economic, social, and environmental, and less frequently extended to spatial or institutional (political) dimensions,

- means a desirable living environment and a responsible society that implements the concept of intra- and intergenerational order [14].

In the "Society" subsystem, the following elements relevant to sustainable processes can be distinguished: health, employment, education, culture, capital value, public involvement, and legal order. The prime goal of sustaining the "Society" system is to achieve social welfare, measured, to a significant extent, by quality of life. The "Economy" subsystem embraces productivity, capital value, business and commercial activity in free market conditions, and legal order. The prime goal for sustaining the "Economy" subsystem is to pursue sufficient quantity and quality of goods in order to build an ecologically and socially sustainable economy. The elements of sustaining the "Environment" subsystem include: production of oxygen by plant organisms, supply of large amounts of "purified water" in the form of water vapor, air purification, creation of microclimate, health impact on various organisms, creation of conditions for the development of flora and fauna (biodiversity), counteracting the greenhouse effect by assimilating carbon from the air and enriching soil with processed compounds, including carbon compounds, economic significance and capital value, aesthetic values [15].

Undoubtedly, systemic sustainable development is a conglomerate of values and a compromise between the environmental, economic, and social goals that contribute to the welfare of present and future generations [16].

\section{Research Methodology-Materials and Methods}

The study is of an exploratory nature and constitutes a preliminary stage to further research into issues related to several sectors, which are of interest to the author. Table 1 shows the characteristics of the research procedure adopted in order to achieve the objective of this article.

Table 1. Basic information on the conducted survey.

\begin{tabular}{cc}
\hline Specification & Characteristics \\
\hline \multirow{2}{*}{ research methodology } & $\begin{array}{r}\text { the analysis of industry journals, websites, sponsored interviews, } \\
\text { personal interviews }\end{array}$ \\
\cline { 2 - 2 } character of research & $\begin{array}{c}\text { surveys, electronic survey with } 46 \text { managers in public transport companies } \\
\text { direct interview, CATI (computer-assisted telephone interviewing) in 16 Regional } \\
\text { Transport Infrastructure Departments }\end{array}$ \\
\hline sample selection & targeted selection of typical units, based on rankings in trade journals \\
\hline sample size & $\begin{array}{c}\text { 46 (firms)/16 (infrastructure departments) } \\
\text { over 100 websites of public passenger transport companies, including utilities, } \\
\text { organizations associating entities from the transport service sector, industry } \\
\text { associations, municipal halls; the website of Poland's Ministry of Infrastructure, } \\
\text { Mobility and Transport- the EU's website }\end{array}$ \\
\hline geographical scope & EU \\
\hline time scope & 2017-2020 \\
\hline
\end{tabular}

The 46 studied companies are providers of the city passenger transport, which meets at least two of the following three conditions: 
- $100 \%$ of buses meet the EURO - (European emission standards),

- at least $50 \%$ of vehicles are powered by CNG-(compressed natural gas),

- at least $50 \%$ of vehicles are used for less than 5 years.

The data were confirmed in the 16 Provincial Road Transport Inspectorates.

The model showed in this elaboration, is constructed on the basic of own elaboration and systemic compilation of scientist view of R. Seidler and K.S. Bawa [17], D. Banister [18] (pp. 73-80), and E. Feitelson [19] (pp. 99-118).

\section{Sustainable Transport Development in the European Union-Results of Desk Research}

A sustainable transport system is the system that meets the basic need of individuals and society to access it in a safe manner consistent with human health and ecosystems and fulfils the requirements of capital values within and between generations; it is affordable and efficient, it offers a choice of modes of transport and supports a thriving economy; it reduces emissions and waste taking into account the planet's capacity of their absorption, minimises the use of non-renewable resources, limits the consumption of renewable resources to sustainable levels, recycles and reuses their components, minimises land use, and reduces noise. According to this definition, sustainable transport must reflect the diverse economic, social, and environmental objectives in a balanced manner (III).

The 2000 White Paper argued: "In achieving sustainable transport development, it is undoubtedly the measures which need to be taken in urban transport which will be the most difficult to implement." [20]. In June 2000, the conference of the European Council clearly indicated the need for the deployment of transport support services (eEurope 2002 Action Plan), integral to the concept of sustainable development. The focus was on intelligent transport systems in cities.

The European Road Transport Research Advisory Council (ERTRAC, 2004/2005) issued a number of materials on sustainable urban transport, including VISION 2020 and the Strategic Research Agenda for the implementation of VISION 2020. VISION 2020 presented a vision of modern road transport that meets the objectives of sustainable development. Both documents identify the three main problem groups:

1. Mobility, transport, and infrastructure

2. Environment, energy, and resources

3. Safety and security.

The issues relating to mobility, transport, and infrastructure involve:

- coordination of integrated urban transport and private vehicles for ready access of citizens to convenient transportation;

- urban deliveries or long-distance hauling as part of goods transport and logistics making efficient use of infrastructure;

- better integration of land-use developments with transport planning in order to eliminate unnecessary demand for transport and parking;

- increased cohesion of urban strategies and urban transport planning taking into account environmental and social dimensions;

- development of prediction models taking into account citizens' transport behaviour and analysing the impact of e-services on that behaviour;

- appropriate location of warehouses and local logistics centres;

- creation of new concepts for environmentally friendly road vehicles providing transport services;

- development of new concepts in the context of safety, noise reduction, and cleanliness in urban transport, especially operating at night;

- integration of different modes of passenger and freight transport through the development of multi-purpose vehicle concepts (e.g., postal bus) and intermodal transport concepts, as well as the possibility of their flexible use in multiple configurations. 
The problems addressed regarding environment, energy, and resources include:

- development of renewable and alternative low-carbon fuels together with advanced vehicle powertrains contributing to security of energy supply and environmental improvement;

- improvements to vehicles, tyres, and infrastructure to reduce transport noise by $10 \mathrm{~dB}$;

- more efficient traffic management, changes in driving behaviour for the development of systems using artificial intelligence and reducing energy use;

- improved vehicle efficiency and reduced pollutant emissions as a result of the development of low-carbon and hydrogen fuels.

Safety and security concerns primarily relate to reducing the number of road fatalities. The core elements of VISION 2020 for safe transport include:

- development of the road infrastructure that is easily understood and designed to minimize road user mistakes and limit their consequences;

- further development of vehicle safety systems to prevent accidents and mitigate their effects;

- protection of sensitive parts of urban areas by reducing unnecessary vehicle traffic in such places;

- development of theft deterrent systems in vehicles;

- $\quad$ improved personal safety systems without violating citizens' privacy (biometrics features).

The Europe 2020 strategy places the greatest emphasis on the need for technological progress in the transport sector, which aims to contribute to reduced resource consumption and lower emission of greenhouse gases and other harmful compounds. In turn, the Communication "A resource-efficient Europe" stresses the need to intensify the positive effects of the transport sector by developing a low-carbon, resource-efficient, secure, and competitive transport system by 2050 that removes all obstacles to the internal market for transport, promotes clean technologies, and modernises transport networks [21,22]. The Communication "A resource-efficient Europe" also points to the necessary changes to the transport pricing system so that it reflects the full costs of mobility.

In Poland, the principles of sustainable transport development were defined in the strategic government programme "The National Transport Policy for 2006-2025". The principles are based on the European transport policy [23]. The strategy is accompanied by the document: "The National Transport Policy for 2006-2025", which contains eight principles of sustainable transport development, presented in Table 2.

The resolution of the Council of Ministers adopted on 24 September 2019 on the "Strategy for the Sustainable Transport Development by 2030" highlighted the need to increase the transport accessibility of the country and improve the safety of traffic participants and the efficiency of the transport sector by creating a coherent, sustainable, innovative, and user-friendly transport system at national, European, and global levels. According to the strategy, the pursuit of the main objective by 2030 requires the following actions:

- building an integrated and interconnected transport network for a competitive economy;

- improving the organization and management of the transport system;

- implementing changes in individual and collective mobility (e.g., promotion of public transport);

- improving the safety of traffic participants and transported goods;

- reducing the negative impact of transport on the environment;

- boosting the efficient use of public funds in transport projects.

Investment efforts are mainly focused on catching up with the infrastructure-related backlog concerning increased transport accessibility in Poland (roads, railways, airports, inland waterways, maritime and inland ports) and on organizing the basic infrastructure of the integrated transport system. This involves increasing transport accessibility of the country, ensuring sustainable development of particular branches of transport, and improving conditions for providing services related to the transport of goods and passengers [24-26]. 
Table 2. Principles of sustainable transport development (2006-2025).

\begin{tabular}{|c|c|}
\hline Principle & Interpretation \\
\hline $\begin{array}{l}\text { 1. Structuring demand for } \\
\text { transport and developing } \\
\text { ways to satisfy it. }\end{array}$ & $\begin{array}{l}\text { curbing the growth in traffic and transport services in some transport } \\
\text { subsystems, limiting the length of journeys, and division of } \\
\text { transport tasks }\end{array}$ \\
\hline $\begin{array}{l}\text { 2. Promoting energy-efficient and } \\
\text { less environmentally damaging } \\
\text { modes and forms of transport }\end{array}$ & $\begin{array}{l}\text { priority for rail, maritime, and inland waterway transport, the use of } \\
\text { electromobility, bicycles, and pedestrian traffic }\end{array}$ \\
\hline 3. Restoring the balance of needs & $\begin{array}{l}\text { it addresses the needs of international, national, regional, and local } \\
\text { transport, as well as its compatibility and intermodality }\end{array}$ \\
\hline 4. Rationalising transit traffic & $\begin{array}{l}\text { integration of routes or nodes of the transit network into the } \\
\text { national network }\end{array}$ \\
\hline 5. Keeping the right proportions & $\begin{array}{l}\text { it concerns balancing the further development of infrastructure with the } \\
\text { maintenance and repairs of existing resources }\end{array}$ \\
\hline $\begin{array}{l}\text { 6. The division of roles in } \\
\text { management, market regulation } \\
\text { and privatisation }\end{array}$ & $\begin{array}{c}\text { it includes leaving as many market segments as possible free to market } \\
\text { play, supporting local governments in their role of organizing public } \\
\text { transport on a local and regional scale, creating joint state and local } \\
\text { government programmes and projects }\end{array}$ \\
\hline $\begin{array}{l}\text { 7. Financing of transport } \\
\text { infrastructure }\end{array}$ & $\begin{array}{l}\text { deployment of integrated forms of payment, remote handling } \\
\text { and e-ticketing }\end{array}$ \\
\hline 8. Privatization & $\begin{array}{l}\text { support for further privatisation of non-urban, suburban and urban bus } \\
\text { transport, as well as privatisation of passenger and freight rail transport, } \\
\text { airports, and local public transport }\end{array}$ \\
\hline
\end{tabular}

\section{Dimensions of Systemic Sustainable Transport Development-Results of Desk and Field Research}

Systematic sustainable transport development means that passenger and freight transport will be carried out in a way that takes into account environmental, social, and economic criteria (Table 3).

The analysis of the research material reveals six dimensions of sustainable transport, represented by specific actions. Area A (use of alternative fuels and new powertrain technologies) includes measures to develop alternative fuel supply infrastructure, reduce the price of alternative fuels, boost production of low-carbon vehicles, create new jobs. Energy efficiency (Area B) concerns the reduction of traditional fuel consumption and electromobility. Transport logistics (Area C) is about interoperability and integrity of the transport system, optimisation and intermodality of transport, and full market competition. Area D (transport infrastructure) involves reducing congestion, traffic monitoring and control systems, improving Intelligent Transportation Systems (ITS) in urban traffic, and promoting alternative citizen mobility and interchange stations. The pro-environmental policy (Area E) includes norms for exhaust emissions and noise, promotion of mobility culture, increases in traditional fuel prices, promotion of alternative fuels. Safety and working conditions (Area F) concern the size, weight and equipment of vehicles, safety monitoring system (tachographs), social security of workers, passenger and/or cargo safety.

In the majority of cases, the respondents classify the actions in "business/economic", (B) "environmental", (E) and "social" (S) categories in the same way as dimensions/actions concerning sustainable transport are classified by the EU (Table 4). 
Table 3. Dimensions of sustainable transport development.

\begin{tabular}{|c|c|c|c|c|c|c|c|c|}
\hline 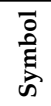 & Area & $\begin{array}{l}\text { हे } \\
\text { है } \\
\text { है }\end{array}$ & Action & $\begin{array}{c}\text { Action } \\
\text { Labelled by } \\
\text { Respondents }\end{array}$ & $\begin{array}{c}\text { Number of } \\
\text { First Choices } \\
\text { Responses in \% }\end{array}$ & $\begin{array}{l}\text { Main Dimensions of } \\
\text { Sustainability According } \\
\text { to Respondents }\end{array}$ & $\begin{array}{l}\text { Policy Priorities of } \\
\text { Local Governments } \\
\text { Responses in \% }\end{array}$ & $\begin{array}{l}\text { Main Dimensions } \\
\text { of Sustainability } \\
\text { According to the EU }\end{array}$ \\
\hline \multirow{4}{*}{ A } & \multirow{4}{*}{$\begin{array}{l}\text { use of alternative fuels } \\
\text { and new powertrain } \\
\text { technologies }\end{array}$} & A1 & development of infrastructure providing alternative fuels & $\mathrm{B}, \mathrm{S}, \mathrm{E}$ & 4 & $\mathrm{~B}-, \mathrm{E}++, \mathrm{S}+$ & 60 & $\mathrm{~B}-, \mathrm{E}+, \mathrm{S}+$ \\
\hline & & A2 & reduced prices of alternative fuels & $\mathrm{B}, \mathrm{S}$ & 4 & $\mathrm{~B}+, \mathrm{S}++$ & 2 & $\mathrm{~B}+, \mathrm{S}+$ \\
\hline & & $\mathrm{A} 3$ & increased production of low-carbon vehicles & $\mathrm{B}, \mathrm{S}, \mathrm{E}$ & 11 & $\mathrm{~B}+, \mathrm{E}++, \mathrm{S}+$ & 12 & $\mathrm{~B}-, \mathrm{E}+, \mathrm{S}+$ \\
\hline & & A4 & job creation & $\mathrm{B}, \mathrm{S}$ & 1 & $\mathrm{~B}+, \mathrm{S}++$ & 34 & $\mathrm{~B}+, \mathrm{S}+$ \\
\hline \multirow{2}{*}{ B } & \multirow{2}{*}{ energy efficiency } & B1 & reduced consumption of traditional fuels & $\mathrm{B}, \mathrm{E}$ & 2 & B-, E++ & 12 & $\mathrm{~B}+, \mathrm{E}+$ \\
\hline & & B2 & electromobility & $\mathrm{B}, \mathrm{E}$ & 17 & $\mathrm{~B}++, \mathrm{E}++$ & 54 & $\mathrm{~B}-, \mathrm{E}++, \mathrm{S}+$ \\
\hline \multirow{3}{*}{ C } & \multirow{3}{*}{ transport logistics } & $\mathrm{C} 1$ & interoperability and integrity of the transport system & $\mathrm{B}, \mathrm{S}, \mathrm{E}$ & 1 & $\mathrm{~B}+, \mathrm{S}+, \mathrm{E}+$ & 11 & $\mathrm{~B}+, \mathrm{E}+, \mathrm{S}++$ \\
\hline & & $\mathrm{C} 2$ & transport optimization and intermodality & $\mathrm{E}, \mathrm{B}, \mathrm{S}$ & 14 & $\mathrm{~B}+, \mathrm{E}++, \mathrm{S}+$ & 54 & $\mathrm{~B}++, \mathrm{E}++$ \\
\hline & & $\mathrm{C} 3$ & full competition & $\mathrm{B}, \mathrm{S}$ & 1 & $\mathrm{~B}+, \mathrm{S}+$ & 6 & $\mathrm{~B}+, \mathrm{S}+$ \\
\hline \multirow{3}{*}{$\mathrm{D}$} & \multirow{3}{*}{$\begin{array}{c}\text { transport } \\
\text { infrastructure }\end{array}$} & D1 & alternative citizen mobility and interchange stations & $\mathrm{B}, \mathrm{S}, \mathrm{E}$ & 1 & $\mathrm{~B}+, \mathrm{S}+, \mathrm{E}++$ & 51 & $\mathrm{~S}+$ \\
\hline & & D2 & reduced congestion; traffic monitoring and control systems & $\mathrm{B}, \mathrm{S}, \mathrm{E}$ & 1 & $\mathrm{~B}+, \mathrm{S}+, \mathrm{E}++$ & 49 & $\mathrm{~B}+, \mathrm{E}+, \mathrm{S}+$ \\
\hline & & D3 & improved urban traffic, ITS & B, S, E & 15 & $\mathrm{~B}+, \mathrm{S}+, \mathrm{E}+$ & 49 & $\mathrm{E}+, \mathrm{S}+$ \\
\hline \multirow{4}{*}{$\mathrm{E}$} & \multirow{4}{*}{$\begin{array}{l}\text { pro-environmental } \\
\text { policy }\end{array}$} & E1 & exhaust emission and noise norms & E & - & E++ & 1 & $\mathrm{E}+$ \\
\hline & & E2 & promotion of mobility culture & $\mathrm{E}$ & 10 & E++ & 11 & $\mathrm{E}+$ \\
\hline & & E3 & increased prices of traditional fuels & $\mathrm{B}, \mathrm{S}, \mathrm{E}$ & - & $\mathrm{B}-, \mathrm{S}--, \mathrm{E}+$ & 7 & $\mathrm{~B}-, \mathrm{S}-, \mathrm{E}+$ \\
\hline & & $\mathrm{E} 4$ & promotion of alternative fuels & $\mathrm{B}, \mathrm{E}$ & 2 & B-, E+ & 8 & B-, E+ \\
\hline \multirow{4}{*}{$\mathrm{F}$} & \multirow{4}{*}{$\begin{array}{l}\text { safety and working } \\
\text { conditions }\end{array}$} & F1 & size, weight, and equipment of vehicles & $\mathrm{B}, \mathrm{E}$ & - & $\mathrm{B}-, \mathrm{E}+$ & 8 & $\mathrm{~B}-, \mathrm{E}+, \mathrm{S}+$ \\
\hline & & F2 & safety monitoring systems; tachographs & $\mathrm{B}, \mathrm{S}$ & 1 & $\mathrm{~B}-, \mathrm{S}+$ & 11 & $\mathrm{~B}-, \mathrm{E}+, \mathrm{S}+$ \\
\hline & & F3 & social security of workers & $\mathrm{S}$ & 4 & $\mathrm{~S}+$ & 7 & $\mathrm{~S}+$ \\
\hline & & $\mathrm{F} 4$ & passenger and/or cargo safety & $\mathrm{B}, \mathrm{S}$ & 11 & $\mathrm{~B}+, \mathrm{S}++$ & 41 & S+ \\
\hline
\end{tabular}

Description: S-social dimension, E-environmental dimension, B—business/economic dimension; Intensity and nature of impact: +/-—positive/negative moderate impact, ++/--— positive/negative strong impact. 
Table 4. Dimension and direction of the sustainability gap.

\begin{tabular}{|c|c|c|c|c|c|c|c|c|c|c|c|c|c|c|c|c|c|c|c|c|}
\hline & A1 & A2 & A3 & A4 & B1 & B2 & $\mathrm{C} 1$ & C2 & C3 & D1 & D2 & D3 & E1 & E2 & E3 & E4 & F1 & F2 & F3 & F4 \\
\hline & $\mathrm{E}+$ & & & & & & & & & & & & & & & & & & & \\
\hline A1 & & $\mathrm{S}+$ & E+ & & & & & & & & \multirow{6}{*}{\multicolumn{7}{|c|}{$\begin{array}{c}\text { MAJOR DIMENSIONS } \\
\text { OF SUSTAINABILITY } \\
\text { ACCORDING TO } \\
\text { RESPONDENTS }\end{array}$}} & & & \\
\hline A2 & & & B+ & & & & & & & & & & & & & & & & & \\
\hline A3 & & & & $\mathrm{S}+$ & E+ & & & & & & & & & & & & & & & \\
\hline A4 & & & B- & & B- & & & & & & & & & & & & & & & \\
\hline B1 & & & & & & $\mathrm{B}++$ & & & & & & & & & & & & & & \\
\hline B2 & & & & & B+ & & & & & & & & & & & & & & & \\
\hline $\mathrm{C} 1$ & & & & & & B- & & $\mathrm{S}+$ & & & & & & & & & & & & \\
\hline $\mathrm{C} 2$ & & & & & & $\mathrm{~S}+$ & $\mathrm{S}+$ & & & E++ & & & & & & & & & & \\
\hline C3 & & & & & & & & B+ & & B+ & & & & & & \multirow{5}{*}{\multicolumn{5}{|c|}{$\begin{array}{l}\text { CONVERGENCE } \\
\text { AREAS OF THE } \\
\text { DIMENSIONS OF } \\
\text { SUSTAINABILITY }\end{array}$}} \\
\hline D1 & & & & & & & & & & & E+ & & & & & & & & & \\
\hline D2 & & \multirow{7}{*}{\multicolumn{6}{|c|}{$\begin{array}{l}\text { MAJOR DIMENSIONS } \\
\text { OF SUSTAINABILITY } \\
\text { ACCORDING TO THE EU }\end{array}$}} & & & & & B+ & & & & & & & & \\
\hline D3 & & & & & & & & & & & & & $\mathrm{E}+$ & & & & & & & \\
\hline E1 & & & & & & & & & & & & & & $\mathrm{E}+$ & & & & & & \\
\hline E2 & & & & & & & & & & & & & & & S- & & & & & \\
\hline E3 & & & & & & & & & & & & & & & 4 & & & & & \\
\hline E4 & & & & & & & & & & & & & & & & & $\mathrm{S}+$ & & & \\
\hline F1 & & & & & & & & & & & & & & & & & & E+ & & \\
\hline F2 & & & & & & & & & & & & & & & & & & & & $\mathrm{S}+$ \\
\hline F3 & & & & & & & & & & & & & & & & & & & & B+ \\
\hline F4 & & & & & & & & & & & & & & & & & & & & \\
\hline
\end{tabular}

Source: own elaboration. 
The key dimensions of sustainable transport development, as indicated by the respondents (the highest percentage of first choices), were electromobility(IV) (B2), improved urban traffic and ITS(V) (D3), and transport optimisation and intermodality(VI) (C2), coming from three different areas of sustainable development. The actions that the respondents indicated as key are also priorities of local government policies (regional and local), in addition to the most important measure identified by this group of respondents involving the development of alternative fuel supply infrastructure, support of alternative citizen mobility and interchange stations, reduced congestion, traffic monitoring and control systems, passenger and/or cargo safety. Moreover, transport optimization and intermodality are generally recognized as a key action with a strong positive business/economic and environmental impact $(\mathrm{C} 2 \mathrm{~B}++, \mathrm{C} 2 \mathrm{E}++)$. Electromobility, crucial for the respondents $(\mathrm{B} 2 \mathrm{E}++, \mathrm{B} 2 \mathrm{~B}++)$, while exerting a moderate negative impact according to the EU (B2B-), was also classified as one of the actions with a high positive business/economic and environmental impact. According to the respondents, a strong positive environmental impact is also manifested by the development of alternative fuel supply infrastructure (A1E++), increased production of low-carbon vehicles (A3E++), reduced consumption of traditional fuels $(\mathrm{B} 1 \mathrm{E}++)$, alternative citizen mobility and interchange stations (D1E ++ ), reduction of traffic congestion, traffic monitoring and control systems (D2E++), exhaust and noise emission norms $(\mathrm{E} 1 \mathrm{E}++)$, and promotion of mobility culture (E2E++). On the other hand, a high positive impact in the social dimension was assigned to the reductions in alternative fuel prices (A2S++), job creation $(\mathrm{A} 4 \mathrm{~S}++)$, and passenger safety $(\mathrm{F} 4 \mathrm{~S}++)$.

\section{Discussion and Conclusions}

Systemic sustainable development is a conglomerate of public administration entities, companies operating in the sector, individual and corporate customers, acting in certain conditions for economic, social, and environmental well-being, and a number of their initiatives of major or minor significance, grouped in six sub-areas, undertaken to achieve systemic value in the examined sector, with a positive or negative business/economic, social, and environmental impact.

The dimensions of sustainable development for the transport service sector are reflected in specific actions, perceived and evaluated in terms of importance and a positive/negative impact, and forming a common core of priorities in the system of activities conducted by the examined entities. It gives the real area of exploration for scientists and entities of the sector. Figure 1 presents the model of systemic sustainable development in the transport service sector, which is the result of this study.

The constructed model contains a list of priorities of the sustainable transport policy according to the requirements of the European Union, local government and industry policy entities in Poland and sector entities. It is a tool for identifying areas of convergence/divergence of dimensions of sustainability, i.e., development gaps in the researched area.

According to the respondents, the most significant actions with the strongest positive impact are the domain of interweaving dimensions: economic, social, and environmental. Figure 1 gives us the gaps that determine the level of compatibility and systemic character of the systemic sustainable development in the transport service sector.

Undoubtedly, systemic sustainable development, also in the transport service sector, is a kind of compromise between environmental, economic, and social objectives that underlie the welfare of current and future generations, pursued by national and local authorities, EU institutions, competing transport companies and customers (passengers). Nevertheless, the systemic nature of sustainable development is expressed in the integrity of its dimensions and in the compatibility and cohesion of the actions taken by stakeholders (VII).

I. The compatibility of intelligent development and sustainable development found its reflection in the works of the European Commission that indicated three priorities in the document "Europe 2020. A strategy for smart, sustainable and inclusive growth": 
- smart growth: development of knowledge and innovation-based economy;

- sustainable growth: support for the economy that uses resources efficiently, is more environmentally friendly and more competitive;

- inclusive growth: support for the economy with high employment that ensures social and territorial cohesion [27-30] (p. 5).

II. More on the subject of formation of systemic values in [30,31].

III. This definition was adopted by the European Conference of Ministers of Transport in 2004 and by the Centre for Sustainable Transportation in 2005. It is the definition of choice for many experts, including the Transportation Research Board's Sustainable Transportation Indicators Subcommittee and the European Council of Ministers of Transport, as well as the Canadian Centre for Sustainable Transportation.

IV. Electromobility embraces the entirety of issues relating to the use of electric vehicles (EV). The term "electromobility" refers to both technical and operational aspects of EV, charging technology and infrastructure, as well as socio-economic and legal issues related to the design, manufacture, acquisition, and use of electric vehicles. The Electromobility Development Plan envisages steps towards building infrastructure that will ensure the functionality of the electric car equal to that of the combustion engine. The Electromobility Development Programme defines multifaceted objectives to be achieved through the development of electromobility in Poland: support for the development of the electromobility ecosystem (by, for example, defining the boundaries of the development of a new economic system), increased demand for other alternative fuels (e.g., liquefied and compressed natural gas), benefits to public transport, innovative entrepreneurs building the infrastructure, vehicle manufacturers and, above all, drivers [32,33].

V. Intelligent Transportation Systems (ITS) cover a wide range of tools based on information technology, wireless communication, and vehicle electronics, which ensure efficient and effective management of transport infrastructure and passenger service. Intelligent Transport Systems are built using connections between a variety of telematics concepts, which people can control with special tools. ITS combines electronics, telecommunications, and information technologies with transport engineering in order to plan, design, operate, maintain, and manage transport systems $[33,34]$.

VI. Intermodal (combined) transport-transportation of passengers/freight using more than one mode of transport. Combined transport in practice usually consists of combining road transport with rail transport. In the classic definition of intermodal transport, the transport process involves moving goods with different means of transport or moving goods in the same vehicle on the whole route in the case of a door-to-door arrangement. The concept of intermodality adopts a deeper meaning in the age of sharing, reducing consumption, and making life greener. This is manifested in integrated bike sharing, car sharing, park and ride, and pre-paid Transport Service Cards. This approach to intermodality is supported by the development of applications such as: mytaxi, movel, Nextbike, and others. Additionally, such practices lead to a decreased use of passenger cars and rationalization of transport as well as counteracting many other civilization-related consequences [34].

VII. The article was inspired by a master's thesis written by D. Pajunk and entitled "Integration of Public Transport for the Concept of Balanced Development of the Service Sector"; University of Economics, 2020, supervisor prof. UE dr hab. Izabela Sztangret 


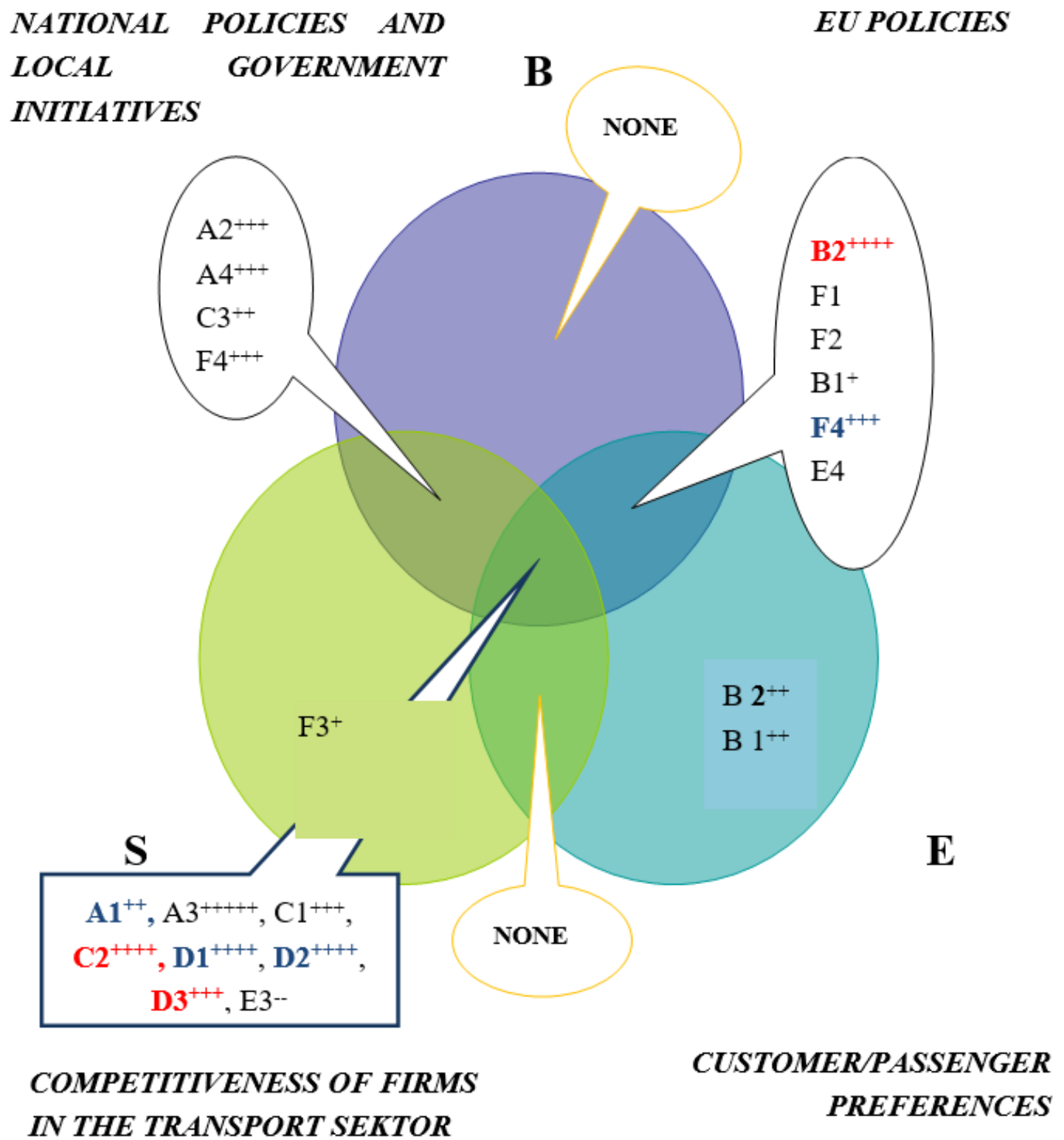

Figure 1. The model of the systemic sustainable development in the transport service sector. Source: own elaboration. Description: B-business/economic dimension, S-social dimension, E-environmental dimension, +/- positive/negative overall impact, key actions according to the respondents, actions of particular importance according to the respondents.

Funding: This research received no external funding.

Conflicts of Interest: The author declares no conflict of interest.

\section{References}

1. UNCED. Agenda 21; United Nations Conference on Environment and Development (UNCED) United Nations: Rio de Janeiro, Brazil, 1992.

2. Kates, R.W.; Corell, R.; Hall, J.M.; Jaeger, C.C.; Lowe, I.; McCarthy, J.J.; Schellnhuber, H.J.; Bolin, B.; Dickson, N.M.; Faucheux, S.; et al. Sustainability Science. Science 2001, 292, 641. [CrossRef] [PubMed]

3. Stappen, R. Raport Brundtland; Brundtland Report; Oxford University Press: New York, NY, USA, 2006. 
4. Gallopín, G. A Systems Approach to Sustainability and Sustainable Development; Sustainable Development and Human Settlements Division ECLAC/Government of the Netherlands Project NET/00/063 “Sustainability Assessment in Latin America and the Caribbean" Medio Ambiente y Desarrollo 64 Santiago, Chile, March. 2003. Available online: https://repositorio.cepal.org/bitstream/handle/11362/5759/S033119_en.pdf (accessed on 4 May 2020).

5. Gerwin, M. Plan Zrównoważonego Rozwoju dla POLSKI: Lokalne Inicjatywy Rozwojowe. Sustainable Development Plan for Poland: Local Developmental Initiatives. Available online: http://www.sopockainicjatywa. org/earth/pdf/LIR-new.pdf (accessed on 11 June 2020).

6. Kozłowski, S. Przyszłość Ekorozwoju. The Future of Eco-Development; John Paul II Catholic University of Lublin: Lublin, Poland, 2005.

7. Cruz, I.; Stahel, A.; Max-Neef, M. Towards A Systemic Development Approach: Building on the Human-Scale Development Paradigm. Ecol. Econ. 2009, 68, 2021-2030. [CrossRef]

8. Spruill, N.; Kenney, C.; Kaplan, L. Community Development and Systems Thinking: Theory and Practice. Natl. Civ. Rev. 2001, 90, 2001. [CrossRef]

9. Flander, K.; Brugmann, J. Pressure-Point Strategy: Leverages for Urban Systemic Transformation. Sustainability 2017, 9, 99. [CrossRef]

10. Sala, S.; Ciuffo, B.; Nijkamp, P. A Systemic Framework for Sustainability Assessment. Ecol. Econ. 2015, 119, 314. [CrossRef]

11. Ehrenfeld, J.R. Sustainability by Design: A Subversive Strategy for Trans forming Our Consumer Culture New Haven; Yale University Press: London, UK, 2008.

12. Werbach, A. Strategy for Sustainability: A Business Manifesto; Harvard Business Press: Boston, MA, USA, 2008.

13. Pezzey, J.C.V.; Toman, M.A. The Economics of Sustainability. Rev. J. Artic. 2002. [CrossRef]

14. Borys, T.; Brzozowski, T. Analiza istniejących danych statystycznych pod katem ich użyteczności dla określenia poziomu zrównoważonego rozwoju transportu wraz z propozycją ich rozszerzenia. Raport z realizacji ekspertyzy. Jelenia Góra-Warszawa. Logistyka 2014, 3, 7254-7260.

15. Ciegis, R.; Ramanauskiene, J.; Martinkus, B. The Concept of Sustainable Development and its Use for Sustainability Scenarios. Econ. Cond. Enterp. Funct. 2009, 62, 2.

16. White Paper, IV. Rationalizing Urban Transport, and: ANNEX IV: Technological Developments and Intelligent Transport Systems. 2000. Available online: https:/ec.europa.eu/transport/sites/transport/files/themes/strategies/ doc/2001_white_paper/lb_com_2001_0370_en.pdf (accessed on 11 November 2020).

17. Seidler, R.; Bawa, K.S. Dimensions of Sustainable Development; Encyclopedia of Life Support Systems (EOLSS); University of Massachusetts Boston: Boston, MI, USA, 2019.

18. Banister, D. The Sustainable Mobility Paradigm. Transp. Policy 2008, 15, 73-80. [CrossRef]

19. Feitelson, E. Introducing Environmental Equity Dimensions into the Sustainable Transport Discourse: Issues And Pitfalls. Transp. Res. Part D Transp. Environ. 2002, 7, 99-118. [CrossRef]

20. Communication from the Commission to the European Parliament, the Council, the European Economic and Social Committee and the Committee of the Regions A Resource-Efficient Europe-A Flagship Initiative under the Europe 2020 Strategy. Available online: http://ww.w.xploit-eu.com/pdfs/Europe\%202020\%20Flagship\% 20Initiative\%20INNOVATION.pdf (accessed on 11 November 2020).

21. White Paper: Roadmap to a Single European Transport Area-Towards a Competitive and Resource Efficient Transport System. COM. Available online: https://eur-lex.europa.eu/legal-content/EN/ALL/?uri=CELEX\% 3A52011DC0144 (accessed on 11 November 2020).

22. Strategy for Sustainable Transport Development to 2030 Adopted with the Resolution No. 105/2009 of the Council of Ministers as of 24 September 2019 (M.P. Item 1054). Available online: https:/constructionmarketexperts.com/en/ news/a-new-transport-development-strategy-adopted-by-the-government/ (accessed on 11 November 2020).

23. Kiełczewski, D.; Dobrzyńska, B. Ekologiczne problemy zrównoważonego rozwoju, Wyd. Wyższej Szkoły Ekonomicznej w Białymstoku, Białystok. Available online: https://epnp.pl/ebook/A04533_ekologiczne_ problemy (accessed on 11 November 2020).

24. Transport Development Strategy to 2020 (towards 2030) (2013), Resolution No. 6 of the Council of the Ministers (M.P. 2013 item 75). 2013. Available online: http://isap.sejm.gov.pl/DetailsServlet?id=WMP20130000075 (accessed on 25 March 2017). 
25. Motowidlak, U. Rozwój transportu a paradygmat zrównoważonego rozwoju; Studia Ekonomiczne. Zeszyty Naukowe Uniwersytetu Ekonomicznego w Katowicach ISSN 2083-8611 No. 337. 2017. Available online: http: //cejsh.icm.edu.pl/cejsh/element/bwmeta1.element.cejsh-580fb08d-31a0-4518-8e0b-ee23cf6c55f5 (accessed on 11 November 2020).

26. ERTRAC. European Road Transport Research Advisory Council. Available online: https://www.earpa.eu/ earpa/36/ertrac.html (accessed on 11 November 2020).

27. Europe 2020. Flagship Initiatives, European Commission. Available online: www.ec.europa.eu (accessed on 28 March 2019).

28. Europe 2020. A Strategy for Smart, Sustainable and Inclusive Growth; European Commission: Brussels, Belgium, 2020; p. 5.

29. Żabiński, L. Marketing of Systemic Products; PWE: Warsaw, Poland, 2010.

30. Zaremba, P. Plan Rozwoju Elektromobilności w Polsce 'Energia do przyszłości', Ministerstwo Energii Rzeczpospolitej Polskiej. Law Electromobility Altern. Fuels 2018, 17, 317.

31. The Act of 27 April 2001, The Environmental Protection Law. Available online: https://www.global-regulation. com/translation/poland/10093814/the-act-of-27-april-2001\%252c-the-environmental-protection-law.html (accessed on 11 November 2020).

32. Koźlak, A. Inteligentne Systemy Transportowe Jako Instrument Poprawy Efektywności Transportu; Uniwersytet Gdański: Gdańsk, Poland, 2008.

33. Bławat, D.; Kalkowski, K. Transport Intermodalny w Polsce-Teraźniejszość i Przyszłość. Available online: https://www.researchgate.net/profile/Krzysztof_Kalkowski/publication/267981316_Transport_intermodalny_ w_Polsce_-_terazniejszosc_i_przyszlosc/links/545e663c0cf295b561602d97/Transport-intermodalny-w-Polsceterazniejszosc-i-przyszlosc.pdf (accessed on 11 November 2020).

34. Leksykon Transportowy, Wyd. TIMOCOM. Available online: https://www.timocom.pl/lexicon/leksykontransportowy/transport-intermodalny (accessed on 12 June 2020).

Publisher's Note: MDPI stays neutral with regard to jurisdictional claims in published maps and institutional affiliations.

(C) 2020 by the author. Licensee MDPI, Basel, Switzerland. This article is an open access article distributed under the terms and conditions of the Creative Commons Attribution (CC BY) license (http://creativecommons.org/licenses/by/4.0/). 